\title{
PENINGKATAN KAPASITAS PENGELOLAAN BADAN USAHA MILIK DESA SIPATUHU DALAM MENOPANG KAWASAN WISATA DANAU RANAU DI KAB. OGAN KOMERINGULU SELATAN
}

\author{
Bambang Sulistyo*1, Akhmad Rosihan ${ }^{2}$, Hendra Alfani ${ }^{3}$, Alip Susilowati Utama ${ }^{4}$ \\ ${ }^{1}$ Fakultas Keguruan dan Ilmu Pendidikan, Universitas Baturaja \\ ${ }^{234}$ Fakultas Ilmu Sosial dan Ilmu Politik, Universitas Baturaja \\ email: bambangsulistyo@unbara.ac.id
}

\begin{abstract}
The village has a lot of potential that can be developed. In many records, there are three main potentials that villages have in general. First, natural resources, second agricultural products and third potential for local wisdom and culture, where these three potentials can support the development of a tourist village. Since the enactment of Law Number 6 Year 2014 Regarding Villages, there has been a massive movement carried out by various groups to awaken the village's potential. The authority of the village government to develop its territory is wide open, but this spirit requires the participation of all components of the village community and synergy with various groups in a sustainable manner. Based on these matters, the Community Service Team of the University of Baturaja, through the Mitra Village Assistance Program, the Director of Research and Community Service of the Ministry of Research, Technology and Higher Education carried out development assistance activities in Sipatuhu Village, Banding Agung District, Ogan Komering Ulu Selatan, South Sumatra Province becoming a souvenir center village and souvenirs in the Lake Ranau tourist area, through excavating village potentials and enhancing the capacity of governance of the Village Owned Enterprises.
\end{abstract}

Keywords: Village potential, Village-Owned Enterprises, souvenir centers, tourism.

\begin{abstract}
Abstrak
Desa memiliki banyak potensi yang dapat terus dikembangkan. Dalam banyak catatan, ada tiga potensi utama yang dimiliki desa pada umumnya. Pertama, sumber daya alam, kedua hasilhasil pertanian dan ketiga potensi kearifan lokal dan budaya, di mana ketiga potensi ini dapat menunjang pengembangan menjadi desa wisata. Sejak diberlakukannya Undang-Undang Nomor 6 Tahun 2014 Tentang Desa, terjadi pergerakan yang begitu massif yang dilakukan berbagai kalangan untuk membangkitkan potensi-potensi yang dimiliki desa. Kewenangan pemerintah desa untuk mengembangkan wilayahnya semakin terbuka lebar, tetapi semangat ini memerlukan partisipasi seluruh komponen masyarakat desa dan sinergi dengan berbagai kalangan secara berkelanjutan. Berdasarkan hal-hal tersebut, Tim Pengabdian kepada Masyarakat (PkM) Universitas Baturaja, melalui Program Pendampingan Desa Mitra, Direktur Riset dan Pengabdian Masyarakat Kementerian Riset, Teknologi dan Pendidikan Tinggi (PPDM-DRPM Kemristekdikti) menjalankan kegiatan pedampingan pengembangan Desa Sipatuhu, Kecamatan Banding Agung, Kabupaten Ogan Komering Ulu Selatan Provinsi Sumatera Selatan menjadi desa sentra souvenir dan oleh-oleh di kawasan wisata Danau Ranau, melalui penggalian potensi desa dan peningkatan kapasitas tata kelola Badan Usaha Milik Desa (BUMDes).
\end{abstract}

Kata kunci: Potensi desa, Badan Usaha Milik Desa, sentra souvenir, pariwisata 


\section{PENDAHULUAN}

Pengembangan desa, sebagai salah satu kegiatan pembangunan, diupayakan dapat sejalan dengan konsep dan prinsip pembangunan berkelanjutan, dengan menerapkan diantaranya pengembangan pariwisata yang berorientasi jangka panjang dan keberlanjutan yang disesuaikan dengan karakter wilayah dan konteks sosial serta dinamika budaya. Tentu upaya ini dalam rangka memperkuat basis ekonomi guna mewujudkan kemandirian dan kesejahteraan masyarakat desa.

Selama ini, menurut Sutoro Eko dkk. (2017:74-75), sebagai basis ekonomi, desa mempunyai berbagai aset. Berbagai aset ekonomi tersebut antara lain adalah hutan, kebun, sawah, tambang, sungai, pasar, lumbung, perikanan, kerajinan dan objek wsiata yang bermanfaat untuk sumber penghidupan warganya.

Hal senada juga disebutkan oleh Christina Maryanti dkk. (2001:58-59, bahwa desa tidak boleh hanya diposisikan sebagai sumber komoditas ekonomi oleh siapapun yang berada "di luar" desa. Apalagi jika diposisikan dalam konteks kepentingan politik, tindakan represif atas nama negara, ataupun tekanan para pemilik modal untuk mengekplorasi potensi-potensi yang dimiliki desa. Potensi ekonomi desa haruslah dipandang sebagai modal yang kuat bagi desa untuk mewujudkan keberdayaan dan kemandiriannya dalam berbagai konteks kepentingan kehidupan orang di desa. Artinya, desa berhak mengelola potensi dan sumber daya yang dimilikinya, "orang luar" boleh berkontribusi, tetapi tetap saja harus mengikuti code of conduct yang tercermin dalam serat-serat kearifan lokal yang dianut desa dan masyarakatnya selama ini.
Salah satu desa yang memiliki potensi dan karakter wilayah yang menarik, adalah Desa Sipatuhu, yang merupakan salah satu desa di Kecamatan Banding Agung, Kabupaten Ogan Komering Ulu Selatan, Provinsi Sumatera Selatan. Desa Sipatuhu, sejak lama dikenal memiliki sumberdaya alam melimpah, khususnya hasil-hasil pertanian. Dua komoditas utama Desa Sipatuhu yang dikenal luas adalah sebagai penghasil kopi robusta dan gula aren terbesar, bukan hanya di Kabupaten Ogan Komering Ulus Selatan, tetapi terbesar Provinsi Sumatera Selatan, sejak zaman Belanda. Potensi Desa Sipatuhu untuk dikembangkan menjadi desa agrowisata sangat terbuka lebar, mengingat posisinya secara geografis berada di kawasan wisata Danau Ranau, danau terbesar kedua di Pulau Sumatera.

Hal yang mendasari Desa Sipatuhu mempunyai potensi untuk dikembangkan menjadi Desa Sentra Souvenir dan Oleh-oleh, dikarenakan Desa Sipatuhu selama ini dikenal sebagai produsen gula aren, gula aren semut, kopi robusta, kopi luwak, dan kopi pinang. Sampai tahun 2017 diketahui jumlah industri kecil dan rumah tangga di Desa Sipatuhu berjumlah 6 usaha industri kecil dengan 25 tenaga kerja, dan terdapat 30 usaha industri rumah tangga dengan 70 tenaga kerja, selain itu di kawasan wisata Danau Ranau belum adanya lokasi souvenir dan oleh-oleh secara massif dan terorganisir.

Potensi yang siginifikan itu, tidak diikuti oleh laju perkembangan yang cepat dan meluas secara berdaya dan mandiri. Akan tetapi potensi itu berkembang sangat lambat dan tidak terorganisir dengan baik, karena pengelolaan tidak malalui Badan Usaha Milik Desa (BUMDes),. Sehingga keuntungan usaha hanya mengalir kepada individu yang banyak modal dan tidak terpusat di suatu tempat. Para pembeli harus mencari oleh-oleh seperti 
gula aren dan kopi dengan berkunjung langsung ke rumah para produsen, sehingga tidak terarah secara sistematis.

Pada konteks ini, diperlukan orientasi dan pemberdayaan bagi segenap komponen masyarakat yang terlibat dalam menumbuhkan usaha ekonomi di desa. Sebab, menurut Ambar Teguh Sulistiyani (2004:80), tujuan yang ingin dicapai dari pemberdayaan adalah untuk membentuk individu dan masyarakat menjadi mandiri. Kemandirian tersebut meliputi kemandirian berpikir, bertindak dan mengendalikan apa yang mereka lakukan serta memutuskan apa yang dipandang tepat untuk dilakukan termasuk memecahkan permasalahan yang mereka hadapi.

Desa Sipatuhu merupakan salah satu desa yang mempunyai potensi desa wisata sebagai Desa Sentra Souvenit dan oleh-oleh kawasan wisata Danau ranau, dimana terletak di Kecamatan Banding Agung, Kabupaten Ogan Komering Ulu Selatan, Provinsi Sumatera Selatan yang berada di ketinggian diatas $700 \mathrm{~m}$ dari permukaan air laut. Mata pencaharian penduduk Desa Sipatahu mayoritas berkebun tanaman Kopi jenis Robusta, Pentani Padi, usaha Gula Aren, dan usaha lainnya. Keberadaan Desa Sipatuhu yang berada tidak jauh dengan kawasan wisata Danau Ranau serta desa yang dilintasi jika ingin pergi dan pulang dari kawasan wisata Danau Ranau, menjadikan Desa Sipatuhu mempunyai posisi strategis sebagai sentra souvenir dan oleh-oleh bagi wisatawan yang berkunjung ke Danau Ranau.

Menurut Badan Pusat Statistik (2018: 24) Desa Sipatuhu memiliki luas 4,60 Km2 dengan kepadatan masyarakatnya 422,17 jiwa/Km2, di mana jika dilihat dari peta seperti yang tergambar pada gambar di bawah ini:

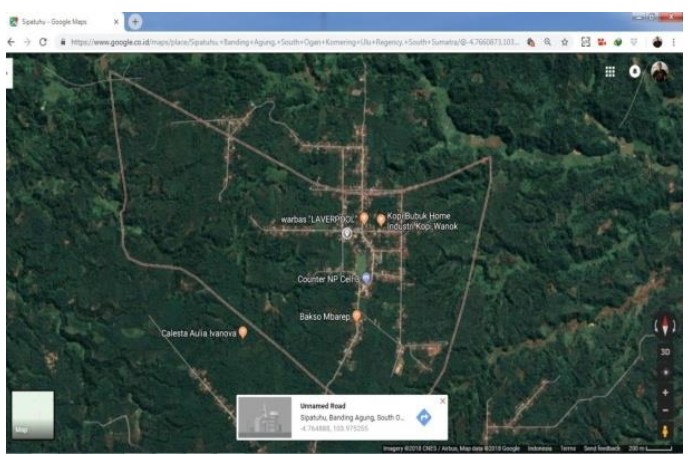

Gambar 1. Peta Desa Sipatuhu, Kecamatan

Banding Agung, Kab. OKU Selatan

(Sumber: Gambar diambil melalui aplikasi Google Map)

Jika dilihat dari gambar di atas terlihat bahwa telah banyak jenis usaha yang sudah ditampil di mesin pencarian Google Map walaupun masih banyak yang belum tampil digambar. Sedangkan jarak Tim dengan Desa Sipatuhu sekitar $130 \mathrm{~km}$ dengan durasi perjalan diperkirakan memakan waktu 3 Jam 11 Menit. Akan tetapi jika jarak Desa Sipatuhu dengan kawasan wisata Danau Ranau hanya sekitar $8.9 \mathrm{~km}$ dengan menempuh perjalanan kendaraan bermotor sekitar 15 Menit, seperti gambar di bawah ini:

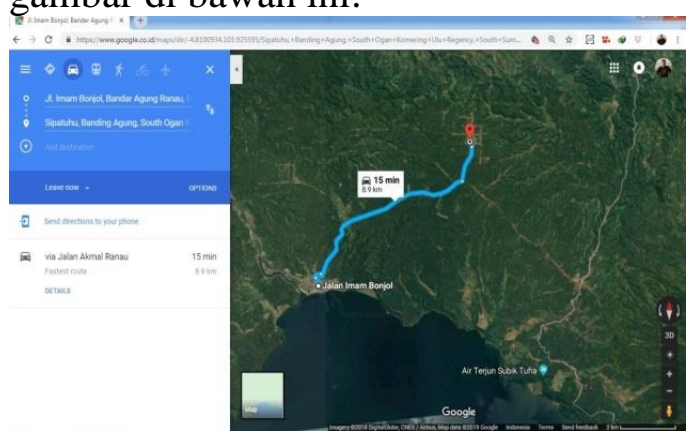

Gambar 2. Jarak Antara Desa Sipatuhu ke Kawasan Wisata Danau Ranau (Sumber:

Gambar diambil melalui aplikasi Google Map)

Sedangkan jarak antara Tim pengusul PkM PPDM dengan lokasi Desa Sipatuhu sekitar $130 \mathrm{~km}$ seperti yang terlihat pada gambar di bawah ini:

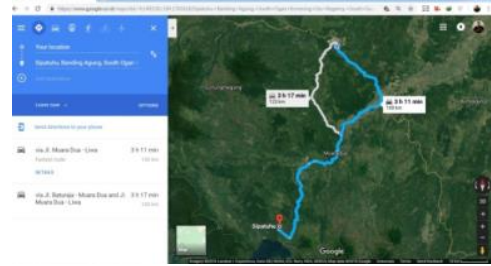

Gambar 3. Jarak antara Tim Pengusul dengan Lokasi Desa Sipatuhu 
Kalau melihat dari luas daerah Desa Sipatuhu yang meliki luas 4,60 $\mathrm{Km}^{2}$ dan melihat jumlah penduduk, maka Desa Sipatuhu termasuk desa cukup padat dan mempunyai potensi berkembang, seperti terlihat pada tabel di bawah ini yaitu jumlah penduduk Desa Sipatuhu:

Berdasarkan data BPS, OKU Selatan dalam Angka 2017, menunjukkan bahwa jumlah penduduk Desa Sipatuhu dengan julah laki-laki sebesar 1.003 jiwa dan perempuan 938 jiwa di mana jumlah keseluruhan dari jumlah penduduk berjumlah 1.941 Jiwa dengan Sex Rasio 107.04.

Potensi Desa Sipatuhu selain dari sumber daya alam yang melimpah, juga memiliki keunggulan dari dari daerah lain. Hal ini dengan adanya data dari Badan Pusat Statistik bahwa Desa Sipatuhu merupakan kawasan Wisata Agro dengan objeknya perkebunan kopi dan aren, seperti yang dipaparkan pada tabel di bawah ini:

Selain terdapat keunggulan tersebut di atas, Desa Sipatuhu juga salah satu desa yang memiliki jumlah usaha industri yang lumayan banyak dibandingkan dengan desa-desa lainnya. Untuk melihat jumlah jenis usaha tahun 2017 yang terdapat 30 jenis usaha industri kecil rumah tangga di Desa Sipatuhu, khususnya usaha bubuk kopi, gula aren, makanan ringan/camilan dan lain sebagainya.

Dari berbagai analisis situasi, potensi, dan nilai strategis dari Desa Sipatuhu di atas terdapat 2 (dua) permasalahan utama yang dihadapi oleh Desa Sipatuhu yaitu,

a) Pertama fungsi BUMDes yang masih belum secara aktif melibatkan masyarakat Desa Sipatuhu serta belum terpetakannya petensi unitunit usaha yang bisa di kelola oleh BUMDes Sipatuhu. Jika melihat Potensi dan nilai strategis yang dimiliki Desa Sipatuhu sangat disayangkan jika BUMDes Sipatuhu belum secara aktif untuk mengelola secara baik. Hal ini dikarenakan masih banyaknya sumber daya manusia khususnya aparatur Desa Sipatuhu mengetahui perencanaan dan pengelolaan BUMDes secara benar dikarenakan akses informasi yang belum dirasakan secara menyeluruh oleh masyarakat Desa Sipatuhu, dan

b) Kedua, masih banyak masyarakat yang belum mengetahui pengelolaan sumber daya alam (kopi, gula aren, pinang) secara baik sehingga menghasilkan produk kurang baik dan harga yang kurang baik, karena jika petani mendapatkan pengetahuan yang baik terkait pengelolaan sumber daya alam diharapakan menghasilkan produk yang baik sekaligus harga yang baik pula, dan diharapkan taraf ekonomi masyarakat Desa Sipatuhu juga meningkat.

Dari 2 (dua) permasalahan yang dihadapi Desa Sipatuhu di atas, dan untuk menampung potensi Desa Sipatuhu sebagai kawasan Wisata Agro serta punya nilai strategis dengan kawasan Wisata Danau Ranau, maka diperlukan perencanaan strategis yang kolaboratif bersama masyarakat dalam merumuskan perencanaan BUMDes yang akuntabel dan transparan dalam pengelolaan unit-unit usaha yang mengelola sumber daya alam Desa Sipatuhu sehingga menjadi Desa Sentra Souvenir dan oleh-oleh di kawasan Wisata Danau Ranau. Tujuan dari Pengembangan Desa Sipatuhu menjadi Desa Sentra Souvenir dan Oleh-oleh di kawasan wisata Danau Ranau diantaranya membantu BUMDes Desa Sipatuhu merencanakan dan mengelola potensi sumber daya alam yang berada di Desa Sipatuhu, menjadi sebuah produk yang bernilai tinggi dan mempunyai harga yang baik, yang terintegrasi dalam 
pengelolaan dengan mengedepankan budaya dan identitas lokal sehingga bisa menjadi rujukan wisatawan yang berkunung di Kabupaten Ogan Komering Ulu Selatan.

Sebagai upaya untuk mewujudkan Desa Sipatuhu menjadi Desa Sentra Souvenir dan Oleh-oleh pada kawasan Wisata Danau Ranau, dan untuk mengatasi 2 (dua) permasalahan prioritas yaitu (1) perencanaan dan pengelolaan BUMDes Desa Sipatuhu belum baik, dan (2) pengolahan sumber daya alam yang masih secara tradisional oleh masyarakat, maka setidaknya diperlukan kepakaran dibidang Ilmu Pemerintahan dalam merencanakan dan mengelola BUMDes secara baik dan benar sesuai dengan Undang-undang Desa, selain itu juga dibutuhkan kepakaran dalam Ilmu Komunikasi untuk merencanakan bentuk materi sosialisasi dan media yang tepat sasaran dan mudah diterima oleh masyarakat, serta dibutuhkan kepakaran dalam bidang pengorganisasian yang terintegrasi sebagai upaya pengembangan Desa Sipatuhu menjadi Desa Sentra Souvenir dan oleh-oleh di kawasan Wisata Danau Ranau.

\section{METODE PENGABDIAN}

Kegiatan Pengabdian kepada Masyarakat $(\mathrm{PkM})$ ini bertujuan untuk meningkatkan kapasitas dan pemahaman aparatur Pemerintah Desa dalam mendorong peningkatan kesejahteraan masyarakat melalui Badan Usaha Milik Desa (BUMDes), sekaligus meningkatkan pengetahuan, manajemen tata kelola (akuntabilitas) pengurus BUMDes serta memetakan peluang pengembangan usaha yang dapat dikelola oleh BUMDes Karya Usaha Desa Sipatuhu sebagai luaran dalam kegiatan program ini. Keseluruhan program kegiatan berdasarkan skim program yang diusulkan oleh Tim PkM PPDM Universitas Baturaja berdurasi selama 1 tahun, dan dapat dilanjutkan pada tahun kedua serta tahun ketiga ketika program ini dapat berjalan dengan pencapaian baik sesuai dengan dengan usulan rencana program.

Adapun pendekatan dalam pelaksanaan kegiatan dilakukan secara koordinatif, persuasif dan edukatif dengan menggunakan metode sebagai berikut:

a) Cermah atau tutorial. Metode ini digunakan untuk memberikan pemahaman dan pengetahuan tentang desa pariwisata, penggalian potensi desa, regulasi dan kebijakan pemerintah yang terkait dengan penyelenggaraan pemerintahan desa dan tata kelola BUMDes serta meningkatkan partisipasi seluruh elemen masyarakat dalam mewujudkan upaya menjadikan Desa Sipatuhu sebagai sentra souvenir dan oleh-oleh di kawasan wisata Danau Ranau.

b) Diskusi/dialog terfokus dengan pemerintah desa dan pengurus BUMDes. Metode ini diarahkan pada tujuan untuk berbagi ide, melahirkan gagasan-gagasan kreatif, mengatasi masalah (tantangan dan hambatan) serta memetakan potensipotensi unggul yang ada di desa dan dijalankan oleh masyarakat selama ini.

c) Anjangsana kepada para pelaku usaha di desa yang berpotensi menjadi mitra usaha BUMDes. Metode ini dilakukan untuk melihat dan mencermati secara langsung potensi usaha yang sudah dijalankan oleh masyarakat sebagai pelaku usaha rumah tangga, yang akan dikembangkan dan menjadi mitra usaha produktif bagi BUMDes.

d) Praktek penggunaan alat-alat pendukung usaha BUMDes yang dihibahkan kepada kepada Pemerintah Desa melalui Pengurus BUMDes. Metode ini dilakukan 
untuk meningkatkan pemahaman dan keterampilan dalam penggunaan alat-alat penunjang usaha yang telah dihibahkan kepada pemerintah desa melalui pengurus BUMDes. Agar alat-alat tersebut dapat dirawat dan digunakan secara efektif-efisien dalam melahirkan produk berkualitas dan bernilai ekonomis.

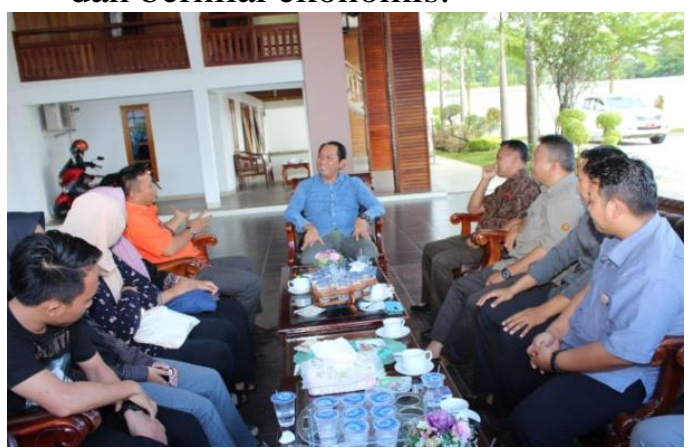

Gambar 4.Koordinasi dengan Bupati dan OPD terkait

Selanjutnya, kegiatan PkM PPDM ini diawali dengan berkoordinasi dengan Pemerintah Daerah Kabupaten Ogan Komering Ulu Selatan, yaitu dengan Bupati, Dinas Pemberdayaan Masyarakat Desa (PMD) dan Camat Banding Agung. Selanjutnya, dalam kegiatan ini dilaksanakan tahapan sebagai berikut:

a) Konfirmasi dan koordinasi dengan Pemerintah Kabupaten Ogan Komering Ulu Selatan, dalam hal ini dengan Bupati, Dinas Pendidikan dan Dinas Pemberdayaan Masyarakat Desa (PMD) sebagai organisasi perangkat daerah yang terkait langsung dengan program PkM PPDM, serta koordinasi dengan Pemerintah Kecamatan Banding Agung sebagai kepala wilayah yang membawahi Desa Sipatuhu.

b) Konfirmasi dan koordinasi dengan Pemerintah Desa dan Badan Permusyawratan Desa (BPD) Sipatuhu, terkait dengan terpilihnya desa ini sebagai lokasi kegiatan DPRM Kemristekdikti, yang dilaksanakan oleh Tim PkM PPDM Universitas Baturaja. c) Tim PkM PPDM melakukan survey lokasi dan pemetaan potensi desa.

d) Persiapan dan perencanaan pelaksanaan kegiatan untuk menetapkan waktu, tempat, materi, sarana prasarana dan peserta serta teknis pelaksanaan kegiatan yang dikoordinasikan dengan Kepala Desa, BPD dan Pengurus BUMDes Desa Sipatuhu.

e) Setelah memperoleh kepastian waktu, tempat dan teknis pelaksanaan kegiatan, Tim PkM PPDM dengan dibantu oleh mahasiswa yang terlibat dalam PkM PPDM, bersama Kepala Desa mengundang pengurus BUMDes dan kelompok masyarakat yang menjadi target sasaran kegiatan untuk mengikuti sosialisasi program.

f) Tahapan berikutnya adalah melaksanakan pelatihan peningkatan pemahaman kebijakan/regulasi pemerintah yang terkait dengan tata kelola BUMDes, manajemen tata kelola, administrasi, serta pengembangan peluang usaha yang dapat dikelola oleh BUMDes sesuai dengan potensi yang ada di desa Sipatuhu.

g) Pelatihan penggunaan (praktek) alatalat pendukung usaha BUMDes seperti .....

h) Pelatihan meningkatkan peluang usaha ekonomi produktif/kreatif bagi ibu-ibu PKK untuk menunjang usaha yang akan dikembangkan oleh BUMDes.

i) Penyerahan alat-alat penunjang pengembangan usaha yang dikelola BUMDes oleh Ketua Lembaga Penelitian dan Pengabdian Masyarakat (LPPM) Universitas Baturaja kepada Kepala Desa dan Pengurus BUMDes Karya Usaha Desa Sipatuhu.

j) Penyusunan dan penyampaian laporan perkembangan pelaksanaan kegiatan PkM PPDM kepada DPRM 
Kemristekdikti, sesuai dengan skim laporan yang telah ditentukan.

\section{HASIL DAN PEMBAHASAN}

Pada tahap awal, Tim PkM PPDM Universitas Baturaja melakukan koordinasi dengan pemerintah setempat (Bupati, Kepala Dinas, Camat dan Kepala Desa), dilanjutkan secara khusus berkoordinasi dengan Pemerintah Desa, BPD dan Pengurus BUMDes Desa Sipatuhu, menjelaskan pelaksanaan pegiatan PkM serta teknis pelaksanaan kegiatan.

Tahap berikutnya Tim PkM PPDM Universitas Baturaja, dengan melibatkan mahasiswa melakukan survei pemetaan potensi desa serta pemasalahanpermasalahan yang dihadapi oleh Pemerintaah Desa dan BUMDes serta para pelaku usaha, terkait dengan pengembangan usaha guna meningkatkan kesejahteraan masyarakat guna menjadikan Sipatuhu sebagai sentra souvenir dan oleh-oleh di kawasan wisata Danau Ranau. Dari dua tahapan itu, akhirnya pada tanggal 22 Juni 2019 disepakati pelaksanaan sosialisasi program dan pelaksanaan tahapan kegiatan PkM PPDM Universitas Baturaja dengan melibatkan unsur-unsur Pemerintah Desa, Pengurusn BUMDes, pelaku usaha, tokoh-tokoh masyarakat di Desa Sipatuhu yang berjumlah 40 orang, di Kantor Kepala Desa Sipatuhu.

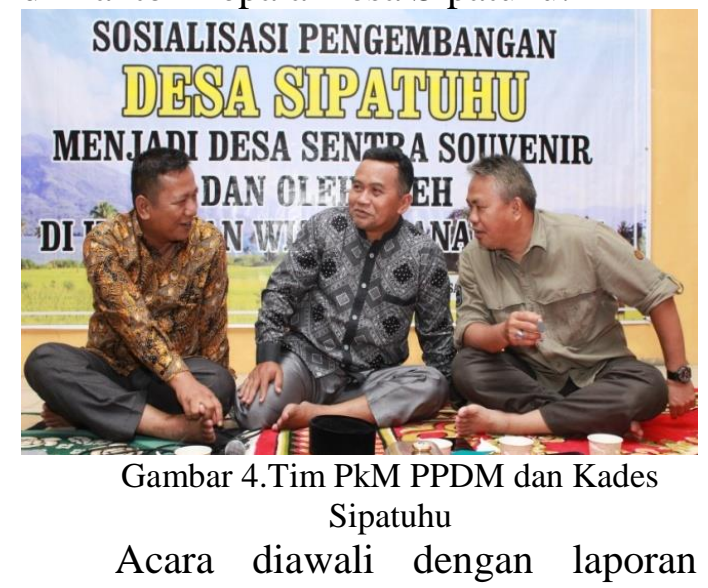

Ketua Tim PkM PPDM Universitas Baturaja, sambutan Kepala Desa dan
Sambutan Camat Banding Agung yang hadir sekaligus membuka acara atas nama Bupati Ogan Komering Ulu Selatan. Ketua Tim PkM PPDM Universitas Baturaja memaparkan tujuan, tahapan dan tujuan yang hendak dicapai oleh kegiatan PkM. Para peserta sosialiasi program sangat antusias merespon materi dan informasi yang disampaikan oleh Tim PkM PPDM Universitas Baturaja. Hal itu terlihat pada sessi diskusi dan tanya jawab, masyarakat secara aktif menyampaikan pertanyaan, pendapat dan masukan terhadap rencana kegiatan program PkM yang akan dilaksanakan oleh Tim PkM PPDM Universitas Baturaja.

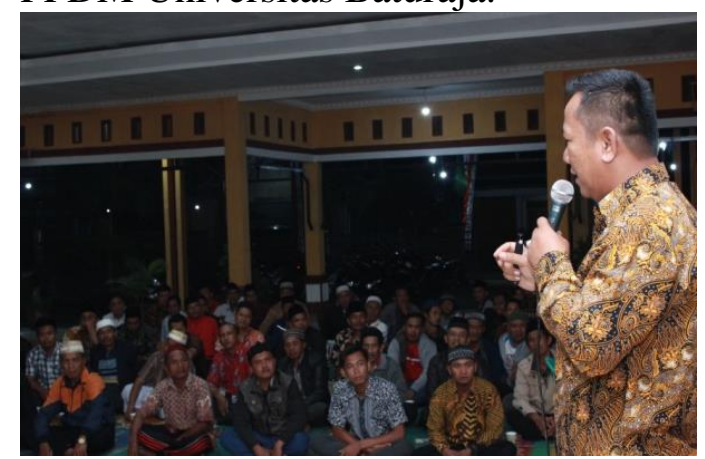

Gambar 4.Ketua Tim PkM PPDM Universitas Baturaja menyampaikan sosialsiasi program PPDM

Pada malam harinya, secara khusus dilanjutkan dengan pembekalan dan orientasi tata kelola BUMDes yang dihadiri oleh para pengurus BUMDEs Karya Usaha Desa Sipatuhu yang telah dibentuk dan ditetapkan dengan Surat Keputusan Kepala Desa Sipatuhu. Materi pembekalan dan diskusi terkait dengan regulasi kebijakan pemerintah tentang Pemdes dan BUMDes, tata kelola, manajemen administrasi dan keuangan serta memetakan peluangpeluang usaha yang dapat dikelola oleh BUMDes dengan menjadikan para pelaku usaha rumah tangga di Desa Sipatuhu sebagai mitra usaha BUMDes. 


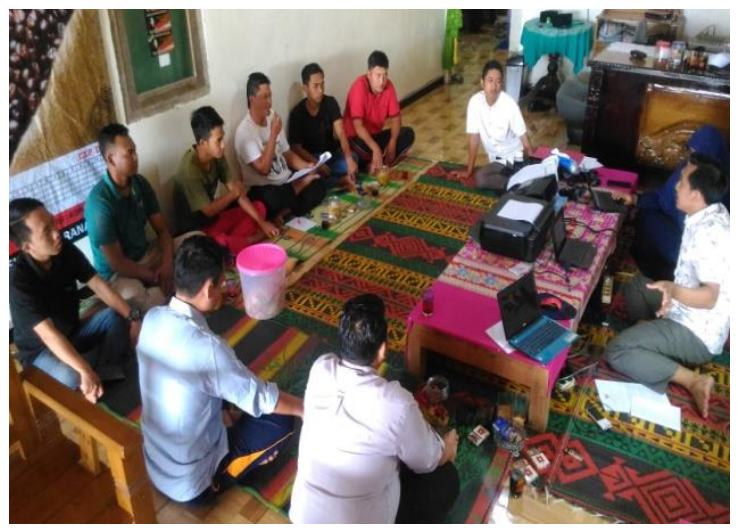

Gambar 6.Diskusi dengan pengurus BUMDes

Selanjutnya, untuk menunjang dan mengembangkan peluang dibukanya unit-unit usaha BUMDes di luar potensi pokok, dalam hal ini kopi dan gula aren, Tim PkM PPDM Universitas Baturaja juga melakukan praktek penggunaan alat pendukung yang dihibahkan dengan dana pembelian alat bersumber dari anggaran PkM PPDM DPRM Kemristekdikti tahun 2019. Praktek penggunaan alat penunjang tersebut antara lain adalah; mesin puppler kopi, mesin penggerak puppler, mesin pembuat kripik, print sablon, mesin press sablon, mesin ukir, mesin gerinda mini, mesin lkaser grafir, plastik packing, dan plastik Ultra Violet (UV) $6 \%$ serta beberapa bahan latihan seperti piring, mug, kaos dan topi untuk bahan latihan.

Mengingat pentingnya peran ibuibu PKK, maka tim juga secara khusus melakukan sosialisasi pengembangan usaha ekonomi produktif. Hal ini dilakukan karena berdasarkan hasil survey pemetaan potensi desa, ibu-ibu rumah tangga yang tergabung dalam PKK, sebagian besar adalah pelaku usaha ekonomi produktif rumah tangga. Produksinya antara lain keripik singkong, keripik talas, kripik pisang, pembuatan gula aren, gula aren semut, kue-kue dan sebagainya. Yang selama ini diproduksi berdasarkan pesanan saja, baik untuk oleh-oleh maupun untuk acara-acara hajatan (perkawinan) dan acara-acara adat lainnya. Respon ibu-ibu
PKK yang dikoordinasi oleh Ibu Ketua PKK Desa Sipatuhu menyambut baik dan merespon dengan antusias upaya pengembangan produksi usaha ekonomi produktif rumah tangga dan siap bermitra dengan BUMDes Desa Sipatuhu.

Secara keseluruhan pelaksanaan program tahap satu atau tahun pertama, berlangsung dengan baik. Hal itu terlihat dari respon para stakeholders di Desa Sipatuhu yang antusias dan bersemangat mewujudkan cita-cita menjadikan Sipatuhu sebagai desa sentra souvenir dan oleh-oleh di kawasan wisata Danau Ranau. Kondisi ini menjadi modal awal yang sangat siginifkan untuk mewujudkan harapan itu. Ketika semua elemen berniat bersama mengembangkan potensi yang dimiliki guna mewujudkan kemajuan, keberdayaan dan kemandirian menuju kesejahteraan bersama.

\section{SIMPULAN}

Setelah pelaksanaan kegiatan PkM PPDM Universitas Baturaja, diperoleh kesimpulan sebagai berikut:

a) Meningkatnya kesadaran dan semangat Pemerintah Desa, Pengurus BUMDes, serta pelaku usaha di Desa Sipatuhu untuk mengembangkan potensi pariwisata desa berbasis produk-produk ekonomi produktif rumah tangga secara kreatif dan berkualitas yang ada di Desa Sipatuhu.

b) Meningkatnya pengetahuan dan keterampilan Pengurus BUMDes, baik dalam memahami regulasi dan kebijakan pengelolaan BUMDes, manajemen pengelolaan (administrasi dan keuangan), memetakan peluang usaha maupun dalam menggunakan alat-alat penunjang usaha BUMDes yang telah dihibahkan.

c) Meningkatnya kesadaran dan kesediaan para pelaku usaha 
ekonomi rumah tangga di desa untuk menjadi mitra usaha BUMDes.

d) Terbangunnya kesadaran bersama untuk mewujudkan Desa Sipatuhu menjadi desa pariwisata berbasis sentra souvenir dan oleh-oleh sebagai penyangga kawasan daerah wisata Danau Ranau.

\section{UCAPAN TERIMA KASIH}

Berikut ini kami sampaikan ucapan terima kasih kepada Direktur Riset dan Pengabdian Masyarakat Kementerian Riset, Teknologi dan Pendidikan Tinggi (DRPM Kemristekdikti) yang telah menerima usulan Program PkM PPDM ini, sekaligus telah memfasilitasi dana program. Selain itu kami juga mengucapkan terima kasih kepada pihak-pihak yang telah membantu kelancaran pelaksanaan Program PkM PPDM ini, mereka antara lain adalah; Rektor Universitas Baturaja, LPPM Universitas Baturaja, Bupati OKU Selatan, Kepala Dinas PMD OKU Selatan, Camat Banding Agung, Kepala Desa Sipatuhu dan Pengurus BUMDes Karya Usaha Desa Sipatuhu. Serta pihak-pihak yang tidak dapat kami sebutkan satu persatu.

\section{DAFTAR PUSTAKA}

[1] Eko, Sutoro, M. Barori dan Hastowiyono. 2017. Desa Baru Negara Lama. Yogyakarta: Pascasarjana STPMD “APMD”.

[2] Maryanti Christina, dkk. 2001. Jaman Daulat Rakyat: Dari Otonomi Daerah ke Demokratisasi. Yogyakarta: LAPERA Pustaka Utama.

[3] Sulistiyani, Ambar Teguh. 2004. Yogyakarta: Gava Media.

[4] Undang-undang Republik Indonesia Nomor 6 Tahun 2014. Tentang
Desa.

[5] Buku Pintar Sistem Administrasi dan Informasi Desa. 2015.

[6] Badan Pusat Statisk. 2017. OKU Selatan dalam Angka. BPS OKU Selatan. 